\title{
PRÁXIS, CONSCIÊNCIA DE PRÁXIS E EDUCAÇÃO POPULAR: ALGUMAS REFLEXÕES SOBRE SUAS CONEXÕES
}

\author{
Aline Maria de Melo Batista*
}

\begin{abstract}
RESUMO
Para consciência comum elevar-se a consciência da práxis, Vázquez (1977) afirma que antes ela deve ascender à consciência reflexiva. Ocorre que Freire (1977), ao idealizar a educação popular, uma educação sustentada na filosofia da práxis educativa, afirma que se deve ir além da consciência reflexiva, destacando o aprofundamento da consciência reflexiva, que seria o processo de conscientização ou forma crítica de abordagem do mundo. O presente artigo visa apresentar algumas reflexões acerca das conexões existentes entre a práxis, a consciência da práxis e a educação popular, no sentido de demonstrar que essas conexões não se dão apenas porque esta última denota uma práxis educativa, mas, porque contribui para consciência da práxis dos sujeitos sociais que se encontram na condição de educandos. Além disso, será enfatizado, a relevância da práxis para educação popular e da educação popular para práxis.
\end{abstract}

PALAVRAS-CHAVE: Práxis. Consciência da praxis. Conscientização. Educação popular.

\begin{abstract}
Common conscience to raise it conscience of the práxis, Vázquez (1977) affirms that before it must ascend to the reflexive conscience. It

Bolsista do CNPq e doutoranda do Programa de Pós-Graduação em Educação da Universidade Federal da Paraíba.
\end{abstract}


occurs that Freire (1977), when idealizing the popular education, an education based in the philosophy of the praxis educative, affirms that it must go beyond the reflection conscience, detaching the deepening of the reflection conscience, that would be the process of awareness or critical form of boarding of the world. The present article aims at to present some reflections concern of the existing connections among the práxis, the conscience of the práxis and the popular education, to demonstrate these connections that do not only give because this last one denotes práxis educative, but because it contributes for conscience of the praxis of the social citizens that find in the condition of students. Besides, it will be emphasized, therefore, the relevance of the práxis for popular education and the popular education for práxis.

KEYWORDS: Práxis. Conscience of the práxis. Awareness. Popular education.

\section{Introdução}

Ao pensar na conexão existente entre a práxis e a educação popular, é comum os estudiosos apontarem para a importância da primeira na construção da segunda, ou seja, da práxis na construção da educação popular. Com isso, este texto pretende demonstrar que essa conexão não se dá apenas porque a educação popular denota uma práxis educativa, mas, porque contribui para consciência da práxis dos sujeitos sociais que se encontram na condição de educandos.

No intuito de contribuir com a discussão que gira em torno dessa temática, parte-se do pressuposto de que a educação popular não transforma o mundo, mas tem um papel central no desenvolvimento crítico das pessoas, isto é, no aprofundamento da tomada de consciência dos sujeitos sociais objetivando a práxis social (atividade de grupos ou classes sociais que leva a transformar a organização e direção da sociedade). Em outras palavras, a educação não transforma o mundo, transforma as pessoas e estas

Educ. e Filos., Uberlândia, v. 21, n. 42, p. 169-192, jul./dez. 2007. 
transformam o mundo. Portanto, para expansão do significado da práxis social, política, coletiva, é fundamental a consciência da práxis (autoconsciência da prática transformadora, revolucionária), e um dos caminhos que possibilita essa consciência é a educação popular, em particular, a que explica as formações ideológicas a partir da práxis material. Assim sendo, este texto fundamenta-se na concepção de práxis em Marx, consciência da práxis em Vázquez e na definição de educação popular formulada por Holliday (2004), por ressaltar que ela sustenta-se em uma filosofia da práxis educativa.

Após a Segunda Guerra Mundial (1939-1945) o mundo ingressa no que os historiadores denominam de história do tempo presente. As transformações ocorridas de lá pra cá, sejam no campo tecnológico, econômico, social e cultural, somadas ao declínio de sistemas políticos e valores que pareciam consolidados, levam a humanidade a rever suas "certezas" (crenças, sonhos, ideologias, utopias), não que ela também não tivesse suas incertezas, mas é sabido que desde o limiar da era moderna as "certezas" prevaleciam motivadas pela razão. Não obstante, o último decênio do século XX é tomado como a marca da grande virada dos novos tempos, com ênfase na derrocada do Muro de Berlim no ano de 1989 e o advento da hegemonia neoliberal, nucleada pela Inglaterra de Margaret Thatcher e pelos EUA de Ronald Reagan. Daí em diante, afirma-se o nascimento de um tempo de incertezas. Um tempo em que a razão iluminista é revisitada e as principais correntes que fundaram suas teorias explicativas do mundo moderno são postas em xeque ou em xeque mate para os mais pessimistas, também chamados de "pós-modernos", isto é, aqueles que, conforme Cardoso (2005), passam a ver o mundo e as sociedades desconfiando da explicação científica e das teorias calcadas em concepções globais.

O fato é que desde o final dos anos oitenta do século passado, fala-se em crise de paradigmas, teorias ou modelos nos diversos campos do conhecimento das ciências sociais, expressas em autores clássicos como Émile Durkheim e Max Weber, bem como Karl Marx, o pai da filosofia da práxis (termo cunhado por Gramsci para substituir a expressão "materialismo histórico"). Essa crise de 
paradigmas, ou crise das correntes de pensamento que fundaram suas teorias explicativas do mundo moderno, se deu mais em relação à crítica a vertente marxista (ou vertentes marxistas) do que a vertente positivista, que já havia sido rejeitada pelo próprio Marx. Isto significa que o pensamento daqueles intitulados de pósmodernos ao confrontar-se com vertentes derivadas do racionalismo atinge, não apenas, mas, sobretudo, as teorias inspiradas no conjunto do pensamento marxiano. Desconsiderando noções como as de sociedade, comunidade, capitalismo, divisão social do trabalho, consciência coletiva, classe social, consciência de classe, nação e, até mesmo, práxis. Atingi-se, conseqüentemente, uma das molas propulsoras da educação popular, a filosofia da práxis educativa, a qual é movida pelas contradições de classes.

Tal contexto possibilita um olhar reducionista da realidade, pois, para enfrentar as incertezas desses novos tempos, é preciso desvelar a realidade social considerando o movimento dialético da história, movimento este, que não se concretizaria sem a existência da práxis dos sujeitos sociais. Conforme Hobsbawm (1995, p. 328),

A revolução cultural de fins do século $X X$ pode assim ser mais bem entendida como o triunfo do indivíduo sobre a sociedade, ou melhor, o rompimento dos fios que antes ligavam os seres humanos em texturas sociais.

Não se retém mais o passado nem se luta mais por um futuro utópico, ostenta-se a defesa de viver o tempo presente, o imediatismo, independentemente do que passou ou do que está porvir, ou seja, o que se entende o porvir como meras incertezas.

O ser humano não pode ser analisado como um indivíduo isolado, mas como um ser histórico-social, síntese de um conjunto complexo de relações sociais. Nessa perspectiva, busca-se romper com as análises de cunho imediatista, reducionista e endógeno. Assim, independente da direção ou paradigma tomado pelos educadores do campo da educação popular, é fato que, conforme 
Scocuglia (1999), o que está no centro das atenções contemporâneas é a permanência de um trabalho educativo anti-excludente e, apesar da heterogeneidade e multiplicidade de formas, práticas e teorias, a educação popular identifica-se através de um núcleo comum (bipolar, mas inseparável) constituído pelo binômio educaçãopolítica, em que, certamente a práxis é seu referencial maior, pois de acordo com Gadotti (2000), elas têm em comum o compromisso com a emancipação humana.

Diante do exposto, o artigo traz algumas anotações sobre as origens e redefinições filosóficas da categoria práxis: a concepção de práxis em Marx e consciência de práxis em Vázquez, e, por fim, uma abordagem acerca da educação popular e suas conexões com a práxis e a consciência de práxis.

\section{Origens e redefinições filosóficas da práxis}

A práxis se configura como uma categoria filosófica que transcorre todo o movimento histórico da humanidade. Não é por acaso que o percurso desse movimento passe por algumas redefinições ao longo dos séculos. Diante disso, será abordado, de forma elíptica, o movimento histórico desde as percepções dos filósofos gregos Platão e Aristóteles, no século II a.C., à concepção de Karl Marx no século XIX.

Ao discorrer sobre a origem do termo, Vázquez (1977) vai buscar na Grécia Antiga o significado semântico da palavra práxis, a qual transcreve em grego, $\pi \rho \sigma_{\xi}^{2}\llcorner\zeta$, utilizado na antiguidade para designar a ação propriamente dita. Uma ação que tem seu fim em si mesma, que não cria ou produz um objeto alheio ao agente ou a sua atividade. Um exemplo dado é a ação moral, intersubjetiva, bem como a atividade política do cidadão tanto nos debates como nas deliberações da comunidade.

Por outro lado, a ação que cria um objeto exterior ao sujeito e a seus atos em grego $\pi 01 \eta \sigma 1 \zeta$, poiésis, que embora no idioma português expresse poesia, significa produção ou fabricação, atividade do artesão, vista como poética, em outros termos, trata-se da atividade prática que produz. 
Segundo Konder (1992), para Aristóteles existiam três tipos de atividades humanas fundamentais: a práxis, a poiésis e a theoria. A práxis era encarada como atividade ética e política, distinta da atividade produtiva, que era a poiésis, enquanto que a teoria representava, exclusivamente, a busca da verdade.

Vázquez (1977) afirma que nessa época o mundo grego, assim como o romano, ignorava ou repelia o mundo prático, pois, diante de um modo de produção escravista, a atividade prática material era considerada própria dos escravos, e a teórica destinava-se aos homens livres, determinando a ruptura entre a ciência e a prática. Logo, nessa divisão social do trabalho, exaltava-se a atividade contemplativa, intelectual. Dessa forma, para Aristóteles, assim como Platão, admitia a legitimidade da práxis política, mas sempre com um nível inferior a vida intelectual, posto que para ambos, o ser humano só se realiza verdadeiramente na vida teórica.

A separação entre teoria e prática, ou entre a ciência e suas aplicações prático-mecânicas, que é característica da Grécia clássica e que serve de base para a atitude depreciativa em relação ao trabalho e às artes mecânicas, não se manifesta em tempos anteriores na Jônia. (VÁZQUEZ, 1977, p. 24).

Assim sendo, a unidade entre ciência e técnica existente nas cidades jônicas contrastava com a atitude depreciativa que prevalecia em Atenas (capital da Grécia). Todavia, vale ressaltar que, de acordo com Vázquez (1977), ainda na Grécia Antiga existiam opiniões que discordavam dessa depreciação da atividade prática produtiva. Tanto é que já em Hesíodo ${ }^{1}$ - poeta grego do século VIII a.C. - revelase o valor do trabalho, expresso em seu poema Os trabalhos e os dias, que demonstra uma valorização da atividade prática e não apenas da atividade contemplativa, intelectual. Conforme o autor, opiniões desse gênero são encontradas, principalmente, entre os sofistas que se pronunciavam contra a escravidão.

1 Sobre Hesíodo ver: JAEGER, W. Paidéia: a formação do homem grego. Tradução de Artur M. Parreira. 3. ed. São Paulo: Martins Fontes, 1994.

Educ. e Filos., Uberlândia, v. 21, n. 42, p. 169-192, jul./dez. 2007. 
A Idade Média segue no ritmo da Antigüidade no que diz respeito à oposição entre teoria e prática, apesar da desintegração da escravidão romana, os camponeses tornaram-se servos dos nobres feudais. De acordo com Silva (1985), os servos viviam em extrema miséria, pois além de estarem presos a terra por força da lei, estavam presos aos senhores, a quem deviam muitas obrigações e impostos. A nobreza e o alto clero compunham a camada dominante dos senhores feudais, ou seja, daqueles que tinham a posse legal da terra, a posse do servo e o domínio do poder político, militar e jurídico.

Portanto, é somente no Renascimento (transição da Idade Média para a Era Moderna) que a consciência filosófica da práxis sofre uma mudança radical, associando-se essa mudança aos nomes de: Leonardo da Vinci, Giordano Bruno e Francis Bacon. Com base nessas mudanças, o homem deixa de ser um animal teórico para ser também sujeito ativo, construtor e criador do mundo, mas também reivindica a dignidade humana não só pela ação contemplativa, como também pela ação prática.

A prática que produz objetos e transforma ganha novo significado, passando a ser vista como condição necessária da própria liberdade humana, que logo, está longe de escravizar o ser humano. Vázquez (1977) assevera que essa idéia do homem como ser ativo que passa a elevar a condição social do artesão e principalmente dos artistas (pintores e escultores), é ressaltada pelos mais notáveis representantes do humanismo renascentista, entre os quais destaca dois nomes, G. Pico della Mirandolla e Leon Bautista Alberti. Este último afirmava que o ser humano não nasceu "para apodrecer deitado, mas para fazer coisas" (GARIN, apud KONDER, 1992, p. 99).

Embora a atividade contemplativa mantivesse um status social superior a própria atividade prática, particularmente a manual, esta já não ocupava mais um lugar desprestigiado na sociedade, ou seja, como algo relegado apenas aos escravos ou aos servos. Não obstante, na Era Moderna, em particular no século XVI, "Maquiavel põe a teoria a serviço da práxis, dando a essa unidade entre as duas um forte acento pragmático" (VÁZQUEZ, 1977, p. 
29), pois buscava uma práxis política funcional a burguesia italiana de seu tempo.

De acordo com Vázquez (1977), a Revolução do século XVIII representa um marco decisivo no processo de ascensão da classe burguesa e de suas idéias de elevação da consciência da práxis produtiva. Tais idéias estão associadas à Francis Bacon, Descartes, bem como aos enciclopedistas franceses e economistas ingleses. Embora os dois primeiros, Bacon e Descartes, engrandeçam o trabalho, não exaltam a figura do trabalhador, pois de certa forma permanecem com a concepção aristotélica de que na atividade teórica encontra-se a força do homem.

Mais tarde, Rousseau, ao contrário dos pensadores iluministas e enciclopedistas franceses, nega a positividade do trabalho produtivo, e será o primeiro a relacionar a transformação da natureza com a transformação do homem, aliás, uma transformação negativa deste, uma vez que, ao refletir sobre as conseqüências do progresso conclui que a transformação da natureza só serviu para degradar e aviltar o homem, antecipando idéias que posteriormente aparecerão em Marx.

O fato é que com o domínio da burguesia no século XIX, o ativismo pragmático, cuja tese fundamental é que a verdade de uma doutrina consiste no fato de que ela seja útil e propicie alguma espécie de êxito ou satisfação do indivíduo, foi prevalecendo e, desse modo, a atividade da produção material, ou seja, a que os filósofos da Grécia Antiga denominavam de poiésis, foi tornandose mais valorizada que a ação intersubjetiva, política e moral dos cidadãos, isto é, do que a própria práxis.

No entanto, conforme Konder (1992), é nesse contexto que a economia política clássica inglesa sublinhava a importância do trabalho, mas não o fazia do ponto de vista dos trabalhadores. $\mathrm{O}$ que significa que a burguesia seguiu valorizando o trabalho e seu produto e, ao mesmo tempo, desprestigiando o trabalhador. $\mathrm{O}$ autor destaca que nos horizontes burgueses da cultura liberal, era impossível realizar a síntese dos dois movimentos (poiésis e práxis), pois a práxis era exercício das elites. Neste sentido, "coube justamente a Marx promover essa modificação decisiva [...]

Educ. e Filos., Uberlândia, v. 21, n. 42, p. 169-192, jul./dez. 2007. 
repensar a relação entre a práxis e a poiésis do ângulo dos trabalhadores" (KONDER, 1992, p.103).

Contudo, não se pode negar que mesmo sem enaltecer o trabalhador, o avanço do pensamento filosófico acerca da atividade prática, ou melhor, o avesso da depreciação em relação ao trabalho no decorrer dos anos, não deixou de ser uma contribuição para Marx repensar e redefinir a práxis. Aliás, uma redefinição que a toma como uma atividade exclusivamente humana, unindo, em um mesmo movimento teoria e prática, distinguindo-se, de tal modo, da prática pragmática, principalmente por objetivar fins transformadores e, em maior nível, revolucionários.

Da concepção de práxis em Marx à definição de consciência de práxis em Vázquez

Embora a práxis na concepção de Karl Marx deite raízes nos Manuscritos econômicos-filosóficos de 1844, é em A ideologia alemãa, de 1845, que ele apresenta uma sistematização da práxis revolucionária, sobretudo nas Teses sobre Feuerbach, as quais recebem posteriormente pequenas reformulações de seu amigo e parceiro intelectual, Friedrich Engels.

A práxis no sentido que Marx atribui, ação transformadora, revolucionária, transcende a condição de simples ação. Contudo, não expressa qualquer ação transformadora, posto que está aprofundada numa concepção dialética da história e da sociedade, une pensamento consciente e ação real, com vistas à transformação radical da sociedade. Isso porque, a práxis torna possível a passagem da teoria à prática, essencialmente, uma prática transformadora, revolucionária.

Todavia, quando se trata de abordar a práxis a partir de uma consciência filosófica que passa a encará-la como atividade humana e que transforma o mundo natural e social, Vázquez (1977) indica como marcos fundamentais não apenas a teoria de Marx, mas também as de Hegel e Feuerbach. Entretanto, assinala a práxis hegeliana como uma práxis teórica que só encontra seu fundamento no próprio movimento teórico do Absoluto (Deus, 
idéia, consciência). A concepção feuerbachiana, por sua vez, gera uma inversão significativa do conceito de práxis, pois a coloca num nível humano substituindo o Absoluto pelo homem real, porém é criticada por Marx como algo que está longe de compreender o conceito de práxis como atividade material produtora, mas sim como uma atividade moral, permanecendo, igualmente, num nível teórico. Destarte, embora Marx tenha sido discípulo de Hegel se opôs a ele ao promover uma nova inversão metodológica, ao estabelecer que não é a consciência que determina a vida, mas a vida é que determina a consciência. Tal inversão encontra-se presente nas onze teses ${ }^{2}$ sobre Feuerbach.

"Em seu conjunto, as onze teses constituem um texto [...]. Com elas esclarece-se o sentido e precisa-se o alcance do conceito central da filosofia de Marx: o conceito de práxis" (KONDER, 1992, p. 123). Dentre essas teses três merecem destaque: a segunda, a oitava e a décima primeira, respectivamente.

II tese

[...] É na práxis que o homem deve demonstrar a verdade, isto é, a realidade e a força, o caráter terreno de seu pensamento...

VIII tese

Qualquer vida social é, essencialmente prática. Todos os mistérios que levam ao misticismo encontram sua solução racional na práxis humana e na compreensão dessa práxis.

XI tese

Os filósofos se limitaram a interpretar o mundo de diferentes maneiras; mas o que importa é transformá-lo. (MARX, 2005, p. 120).

2 As onze teses (sobre Feuerbach) foram escritas por Marx aproximadamente no ano de 1845, mas as que aqui se apresentam receberam mínimas reformulações de Engels, que as publicou no ano de 1888. Sabe-se, porém, que em 1932, a versão original de Marx foi recuperada e publicada como anexo de $A$ ideologia Alemã. Esta obra, no entanto, ao ser republicada pela editora Martin Claret, em 2005, oferece ao público a versão engelsiana, utilizada neste artigo por perceber que as mudanças são, de fato, mínimas.

Educ. e Filos., Uberlândia, v. 21, n. 42, p. 169-192, jul./dez. 2007. 
Uma visão focalizada nessa última tese, a décima primeira, dá impressão de uma elevação da prática sobre a teoria, todavia o que se evidencia no conjunto das supracitadas teses é justamente o contrário, a indissociabilidade e a interdependência entre ambas, por se tratar de uma prática movida por uma teoria, isto é, por uma visão filosófica de mundo.

Ao estabelecer que a fonte real humana é a práxis e não a consciência, Marx se rebela contra o mundo das idéias, dos dogmas, das entidades imaginárias. Com ele atam-se pensamentos de Hegel, Feuerbach, dos economistas ingleses e dos socialistas de seu tempo (VÁZQUEZ, 1977), emergindo, assim, uma concepção marxista da práxis, cuja síntese une, em uma mesma categoria filosófica, as atividades humanas mencionadas por Aristóteles no início dos séculos: theoria, práxis e poiésis.

A práxis na concepção de Marx, não se limitou a unir a theoria e a poiésis, pois envolvia também - necessariamente - a atividade política do cidadão, sua participação nos debates e nas deliberações da comunidade, suas atitudes na relação com outros cidadãos, a ação moral, intersubjetiva. Envolvia, em suma, aquilo que os antigos gregos chamavam de práxis. (KONDER, 1992, p. 128).

A práxis marxista, portanto, pode ser definida como "[...] atividade material do homem que transforma o mundo natural $\mathrm{e}$ social para fazer dele um mundo humano" (VÁZQUEZ, 1977, p. 3). Em um nível mais elevado, "[...] a revolução, ou a crítica radical que, correspondendo a necessidades radicais, humanas, passa do plano teórico ao prático" (VÁZQUEZ, 1977, p. 128), Ou ainda, é a "[...] atividade concreta pela qual os sujeitos humanos se afirmam no mundo, modificando a realidade objetiva e, para poderem alterá-la, transformam-se a si mesmos. É a ação que [...] precisa da reflexão, da teoria; e é a teoria que remete à ação" (KONDER, 1992, p. 115).

Por ser uma atividade exclusiva do ser humano, a práxis marxista, simultaneamente, é subjetiva (por estar presente na 
consciência humana antes da sua materialização) e objetiva (por agir em uma realidade natural que existe independente do sujeito), pois distingui-se da mera atividade subjetiva (psíquica ou espiritual) que, por não se objetivar materialmente, não pode ser considerada como práxis.

Assim, ao ressaltar, sobretudo, o caráter objetivo da práxis, Marx ultrapassa tanto a visão espiritual e abstrata da práxis hegeliana (ligada à consciência) como a visão subjetiva da práxis feuerbachiana (ligada à ação moral). Dessa forma, nota-se o ser humano como sujeito histórico, construtor de suas representações, de suas idéias, de suas relações sociais, econômicas, políticas, porém, sempre levando em consideração o desenvolvimento das forças produtivas, a divisão social do trabalho e as relações de dominação presente entre as classes sociais no interior do sistema capitalista, por influenciarem de forma significativa os rumos da construção histórica.

Não se trata, como na concepção idealista da história, de buscar uma categoria em cada período, mas sim de permanecer sempre no solo real da história; não de explicar a práxis a partir da idéia, mas de explicar as formações ideológicas a partir da práxis material; chega-se em conseqüência disso, ao resultado de que todas as formas e todos os produtos da consciência não podem ser resolvidos por força da crítica espiritual [intelectual] [...] mas só podem ser dissolvidas pela derrubada prática das relações reais das quais brotam essas tapeações idealistas; não é a crítica mas a revolução, a força motriz da história [...]" (MARX e ENGELS, 2005, p. 65-66)

Em vista disso, "em sua tese de doutoramento Marx insistiu na necessidade da filosofia tornar-se prática" (BOTTOMORE, 2003 , p. 293), fazendo nascer uma nova teoria: o materialismo histórico-dialético - também denominado de marxismo - “[...] que não quer permanecer como filosofia, mas transcender-se tanto em um novo pensamento metafilosófico como na transformação revolucionária do mundo" (BOTTOMORE, 2003, P.293), visando 
uma sociedade mais humana. A práxis é, desse modo, tomada como categoria central do marxismo, cuja filosofia, dita de outra forma, se concebe "[...] não como interpretação do mundo, mas também como guia de sua transformação" (VÁZQUEZ, 1977, p. 5).

Nessa perspectiva, desde Marx até os tempos atuais entendese que a práxis transcende a prática pragmática, individual e autosuficiente. Contudo, Konder (1992) afirma que inúmeras confusões podem ser constatadas acerca da práxis marxista, dentre as quais duas se destacam: a primeira é quando a reduzem à prática estritamente utilitária, e a segunda é quando a restringem ao trabalho. Embora ela o envolva, a prática inclui muito mais que o trabalho, isto é, inclui todas as objetivações humanas. Assim, “[...] a práxis, que nasce do trabalho, vai além dele afirmando potencialidades que se multiplicam num sujeito que se diferencia" (KONDER, 1992, p. 125). Essa, pois, trata-se de uma atividade que, para se tornar mais humana, precisa ser realizada por um sujeito mais livre e mais consciente, é a atividade que precisa da teoria. E como bem coloca Vázquez (1977, p.185), “toda práxis é atividade, mas nem toda atividade é práxis".

Esse último autor aponta que, a práxis se apresenta sob diversas formas específicas, mas todas elas são concordantes no fato de se tratar da transformação de uma determinada matéria-prima e da criação de um mundo de objetos humanos ou humanizados, essas são: a práxis produtiva (transformação da natureza pelo trabalho humano, em que o homem se produz, forma ou transforma a si mesmo); a práxis artística (que permite a produção ou criação de objetos humanos ou humanizados que elevam a capacidade de expressão e objetivação humanas); a práxis científica (cuja finalidade imediata é teórica); e a práxis social (atividade de grupos ou classes sociais que leva a transformar a organização e direção da sociedade). Ele apresenta esta última, como uma práxis política cuja forma mais elevada é a práxis revolucionária.

Para a expansão do significado da práxis, em especial da práxis social, é fundamental o que ele define como consciência da práxis, ou seja, "[...] a consciência que se volta sobre si mesma e sobre a atividade material que se plasma" (VÁZQUEZ, 1977, p. 283-284). 
Ela ultrapassa a consciência comum, isto é, o conhecimento imediato, ingênuo, espontâneo, que estabelece uma oposição radical entre teoria e prática. Em virtude disso, o supracitado autor assinala que para a consciência comum alcançar a consciência da práxis é preciso ultrapassar o ponto de vista espontâneo, ascender ao plano reflexivo (consciência reflexiva) que é o plano próprio da atitude filosófica, para só então se unir conscientemente pensamento e ação. Em suma, esse movimento ocorre da seguinte forma: da consciência comum para consciência reflexiva para consciência da práxis.

Contudo, entende-se que para se obter a consciência da práxis é preciso ir além da consciência reflexiva, é necessário a conscientização. Este define-se como

[...] um ato de conhecimento. Implica um desvelamento da realidade com o qual vou me aprofundando [...] para desvelar a sua razão de ser [...]. O processo de conscientização implica [...] um ato lógico de conhecimento e não transferência de conhecimento. [...] não se pode basear na crença de que é dentro da consciência que se opera a transformação do mundo, a criação do mundo. É dentro do próprio mundo que, na história, através da práxis que se dá o processo de transformação (FREIRE, 1979, p. 114-115).

Portanto, como transitar de um ponto de vista espontâneo da consciência comum para uma consciência reflexiva, que transcenda para a conscientização e, enfim, para a consciência da práxis?

Emerge o papel central da educação popular que, ao sustentarse em uma filosofia da práxis educativa, torna-se uma alternativa de mediação dessa transição.

\section{A educação popular e suas conexões com a práxis e a consciência de práxis}

La "educación popular" latinoamericana es, a la vez, un fenômeno sociocultural y una concepción de educación. Como fenômeno sociocultural, la educación popular hace referencia a

Educ. e Filos., Uberlândia, v. 21, n. 42, p. 169-192, jul./dez. 2007. 
una multitud de prácticas con características diversas y complejas, que tienen en comum que encierram una intencionalidad transformadora. [...] Como concepción de educación la educación popular no posue un cuerpo categorial sistematizado en todos sus extremos. Sin embargo, podemos afirmar que apunta a la construción de un nuevo paradigma educativo, que se opone a un modelo de educación autoritario, reproductivista, predominantemente escolarizado y que disocia la teoria de la práctica. [...], y está sustentada en una filosofia de la praxis educativa[...] (HOLLIDAY, 2004, p. 111 112).

O conceito de Holliday, acima mencionado, parte do pressuposto de que a educação popular sustenta-se em uma filosofia da práxis educativa, entendida como um processo políticopedagógico centrado no ser humano como sujeito histórico transformador que se constrói socialmente nas relações com os outros e com o mundo.

Vale salientar que nos dias de hoje ainda ocorre uma discussão a respeito da semântica da educação popular, isto significa que para uns a educação popular refere-se a qualquer educação feita para o povo, para outros trata-se de uma educação própria do povo. Com isso, emerge a seguinte questão: será mesmo que toda educação feita para o povo é educação popular?

Pode ser popular, uma vez que sirva ao povo, mas, se não construída com a participação crítica desse povo, mesmo nomeado como pode vir a contribuir com a reprodução da ideologia dominante. Assim sendo, embora popular, servirá sobretudo a classe dominante. Não basta democratizar a educação alfabetizante para que ela seja, de fato, popular, porém não se deve pensar que educação popular é somente aquela que vem do povo, e sim, a que é feita com o povo, permeada por uma base política estimuladora de transformações sociais.

Na visão freireana, é preciso que essa educação vá além da democratização da alfabetização, deve estar voltada para a conscientização da população, conscientização de sua condição 
social e econômica. Uma educação que haja, conforme Gadotti (2000), um processo sistemático de participação na formação, fortalecimento e instrumentalização das práticas e dos movimentos populares com o objetivo de apoiar a passagem do saber popular ao saber orgânico, ou seja, do saber da comunidade ao saber de classe na comunidade.

A educação popular pensada por Paulo Freire nasce na América Latina, especificamente no Brasil, entre os anos de 1950 e 1960,

[...] no terreno fértil das utopias de independência, autonomia e libertação, que propunham um modelo de desenvolvimento baseado na justiça social. Para esse modelo de educação popular a conquista do Estado era fundamental. Porém, esse processo foi interrompido pela brutal intervenção militarista e autoritária. A educação popular refugiou-se, então, nas organizações não-governamentais e, alguns casos, na clandestinidade (GADOTTI, 2000, p. 292).

Conforme Gadotti (2000), a educação popular tem-se constituído num paradigma teórico que trata de codificar e descodificar os temas geradores das lutas populares, também, busca colaborar com os movimentos sociais e os partidos políticos que expressam essas lutas. Além disso, procura de diminuir o impacto da crise social na pobreza e de dar voz a indignação e desespero moral do pobre, do oprimido, do indígena, do camponês, da mulher, do negro, do analfabeto e do trabalhador industrial. Ele assinala que a grande utopia da educação popular dos anos 1950 visava à conquista do Estado e a mudança radical da política econômica e social. Hoje, o que se assiste é a educação popular dispersando-se em milhares de pequenas experiências, perdendo aquela grande unidade teórica, mas ganhando em diversidade.

Contudo, diante dessa diversidade de práticas que vem se identificando como educação popular, emerge, por parte dos educadores desse campo, a preocupação com a qualidade de tais atividades. Um exemplo disso são as conclusões do Seminário Taller

Educ. e Filos., Uberlândia, v. 21, n. 42, p. 169-192, jul./dez. 2007. 
sobre educação popular na América Latina e no Caribe, realizado em La Paz, Bolívia, no ano de 1990, cujos registros no livro Educação popular - utopia latino-americana demonstraram que as maiores preocupações dos participantes desse seminário eram as crises tanto do discurso como da prática em educação popular, que se expressam, por um lado, na insuficiência do discurso para falar e dar conta da ação e, por outro, nos problemas que afetam as práticas e especificidades no contexto social e político da região. Tais análises não negam os avanços da educação popular, entretanto, apontam os desafios que emergem nesse movimento educativo em face da realidade contemporânea da América Latina.

O consenso das discussões do Seminário Taller reflete que, dado a tendência geral da educação popular, de um discurso ligado a uma leitura das dimensões estruturais da dominação e funcionamento da sociedade, restou pouco espaço para análises teóricas dos problemas cotidianos e processos de constituição da subjetividade dos sujeitos. O que demonstra, para os participantes, um descuido no que tange à compreensão da natureza simbólica das práticas educativas, sua especificidade pedagógica e as características dos cenários e processos cotidianos nos quais estas transcorriam. Além disso, a partir de um olhar em relação à especificidade e rigorosidade interna, constatou-se tanto uma rica variedade de práticas que se identificam como educação popular como a ausência de sistematizações de tais atividades, ou seja, o desconhecimento da qualidade destas.

O debate em questão visa, segundo Gadotti e Torres (1994), melhorar a qualidade dos processos educativos que vêm sendo implementados nos dias de hoje, o que implica, por um lado, analisar com maior profundidade os processos de aprendizagem que se promovem, o problema da transmissão de conhecimento e sua articulação com o saber popular, a transferência dos recursos simbólicos e materiais e a relação de autonomia ou dependência que estabelecem as Organizações Não-Governamentais - ONGs com as organizações sociais, por outro lado, constatar como o problema do Estado surge com importância no debate dos educadores populares. 
Os temas abordados como fundamentais nas conclusões advindas das discussões realizadas no mencionado Seminário, os quais levam a uma maior e melhor reflexão sobre a educação popular, foram os seguintes: 1) educação popular e a construção de um novo discurso; 2) questões metodológicas da educação popular; 3) a transformação de saberes e o problema da autonomia; 4) cultura e educação popular; 5) Estado, poder e educação popular; 6) educação popular e escola pública; 7) gênero e educação popular e 8) formação dos educadores populares. Com as discussões realizadas, concluíram que, perante a diversidade de temas e desafios resulta a necessidade de realizar maiores investigações sobre o trabalho da educação popular. Não apenas da realidade socioeconômica, mas do mundo simbólico da cultura, das concepções do mundo, valores, etc. Investigações que levem em consideração as diferenças.

Enfim, o Seminário reitera que as agências de cooperação deveriam desenvolver estratégias que permitam superar a dissociação entre fazer educação popular e investigar a educação popular. Em outras palavras, deve-se trabalhar para evitar a conhecida divisão entre teoria e prática, problemática que aflige o campo da educação como um todo. Ademais, afirma a necessidade do educador popular abarcar outros níveis de conhecimento, e um deles seria a reformulação do poder, isso porque não se pode afirmar a tentativa da criação de uma sociedade alternativa que, na prática não ocorre a superação da concepção clássica do poder vigente na sociedade.

Toda literatura da educação popular registra, conforme Sales (1999), a preocupação com a transformação da realidade; nesse Seminário da Bolívia não foi diferente, por isso é que não se deve tomar a práxis como uma categoria filosófica obsoleta no pensamento pedagógico, ao contrário, ela está mais do que atual, tendo em vista que, de acordo com Vázquez (1977), une pensamento consciente à ação real, com vistas à transformação radical da sociedade. Para este último autor, o homem comum encontra-se imbricado numa rede de relações sociais e enraizado num determinado terreno histórico e, portanto, sua própria cotidianidade está

Educ. e Filos., Uberlândia, v. 21, n. 42, p. 169-192, jul./dez. 2007. 
condicionada histórica e socialmente, e o mesmo se pode dizer de sua própria atividade prática, ou seja, somente a partir da superação do ponto de vista espontâneo ou instintivo, isto é, da consciência comum, é que se pode unir de modo consciente pensamento e ação.

A educação popular, na busca por uma conscientização das massas, investe de maneira efetiva no pensamento consciente dos sujeitos sociais, sem, contudo, desrespeitar o saber popular, ao mesmo tempo que, na luta pelo protagonismo desses sujeitos, está buscando a ação real dos mesmos. Isso significa dizer que esse paradigma educativo, como práxis educativa (cujo referencial maior é a práxis, a ação transformadora) segue em busca da consciência da práxis das pessoas, uma autoconsciência da prática que visa à transformação da realidade.

Conforme Freire (1977, p. 84) "a educação se re-faz constantemente na práxis". E assevera, "conscientização (...) é um processo humano que se instaura quando a consciência se torna reflexiva" (1979, p.113). Diz, ainda, que mais do que a tomada de consciência, que resulta do simples fato do homem ter uma consciência reflexiva, é o aprofundamento da tomada de consciência, que significa a ultrapassagem do que ele chama de forma cotidiana de abordagem do mundo (consciência comum nos termos de Vázquez) para uma forma crítica de abordagem do mundo, na qual busca-se, não apenas o desvelamento, mas também, a transformação da realidade.

Para uma análise comparativa entre o movimento do processo de conscientização em Freire e o movimento do processo para se obter a consciência da práxis em Vázquez observa-se o quadro abaixo. 


\begin{tabular}{|c|c|}
\hline $\begin{array}{c}\text { FREIRE } \\
\text { (PROCESSO DE CONSCIENTIZAÇÃO) }\end{array}$ & $\begin{array}{c}\text { VÁZQUEZ } \\
\text { (PROCESSO PARA SE OBTER A } \\
\text { CONSCIÊNCIA DA PRÁXIS) }\end{array}$ \\
\hline $\begin{array}{l}\text { Da } \\
\underline{\text { Forma cotidiana de abordagem domundo }}\end{array}$ & $\begin{array}{c}\text { Da } \\
\text { Consciência comum }\end{array}$ \\
\hline $\begin{array}{c}\text { para } \\
\Downarrow \\
\text { Tomada de consciência advinda da }\end{array}$ & $\begin{array}{c}\text { para } \\
\Downarrow \\
\text { Consciência reflexiva (ou plano reflexivo) }\end{array}$ \\
\hline $\begin{array}{c}\underline{\text { O Aprofundamento da tomada de }} \\
\underline{\text { consciência ou Forma crítica de }} \\
\underline{\text { abordagem do mundo }=\text { Conscientização }}\end{array}$ & $\begin{array}{l}\text { Consciência da práxis }= \\
\text { “a consciência que se volta sobre si mesma e } \\
\text { sobre a atividade material que se plasma" ou } \\
\text { autoconsciência da prática transformadora }\end{array}$ \\
\hline
\end{tabular}

A comparação proposta no quadro acima serve como ilustração para demonstrar a importância do processo de conscientização da educação popular proposta por Paulo Freire na construção da consciência de práxis abordada por Vázquez, considerando que é a forma crítica de abordagem do mundo que leva a autoconsciência da prática transformadora, ou melhor, mais do que uma consciência reflexiva é preciso haver o aprofundamento dessa, que seria a conscientização e que leva a consciência de práxi, mas sem esquecer

Educ. e Filos., Uberlândia, v. 21, n. 42, p. 169-192, jul./dez. 2007. 
da anterioridade da práxis sobre a consciência, pois a conscientização proposta pela educação popular se plasma mediante a práxis material.

Segundo Carvalho (2003), a educação popular tem sido historicamente um pré-requisito para a expansão de direitos sociais, sendo nos países em que a cidadania se desenvolveu com mais rapidez, inclusive na Inglaterra, por uma razão ou outra, a educação popular foi introduzida. Então, foi esta que permitiu às pessoas tomarem conhecimento de seus direitos e se organizarem para lutar por eles.

Em síntese, a educação popular sustenta sua proposta teóricoprática nos quatro pilares fundamentais apontados por Hurtado (2004): 1) um marco ético (comprometido com a transformação social); 2) um marco epistemológico (de caráter dialético); 3) uma proposta pedagógica (de cunho democrático); e 4) um marco sóciopolítico (a favor da humanização). Tomando por base os quatro pilares, Hurtado (2004, p.19) relata que a premissa fundamental é “[...] trabajar en la búsqueda de la coherencia, valor fundamental que equilibre la síntesis entre discurso e práctica". (2004, p. 19).

Assim sendo, esse modelo de educação permanece comprometido com um projeto societário de busca pela emancipação das classes subalternas, pois, uma teoria referenciada na realidade aposta em metodologias (pedagogias) incentivadoras à participação e ao empoderamento das pessoas, com conteúdos e técnicas de avaliação processuais permeada por uma base política estimuladora de transformações sociais. Ao valorizar a abertura ao diálogo, o qual permite, inclusive, uma autocrítica, pode ser compreendida como uma alternativa à crise de paradigmas educacionais, sobretudo porque, conforme Gadotti (2000), desde o legado de Paulo Freire, busca consolidar o seu Projeto de Escola Cidadã, ou seja, uma escola estatal quanto ao financiamento, comunitária quanto à gestão e pública quanto à destinação, que vise formar os sujeitos sociais, não para ser controlado pelas esferas do Mercado e do Estado, mas para controlar tais esferas.

Portanto, diferente dos anos iniciais da educação popular que se dava particularmente no campo da educação informal, hoje em dia o que se tem é a busca constante pela inserção desse tipo de 
educação no âmbito da educação formal. Porém, não se deve perder de vista o atrelamento de suas propostas com as idéias e práticas reivindicatórias das camadas marginalizadas, na formação dos indivíduos como cidadãos e protagonistas sociais, pois, a conjuntura dos tempos históricos, pretende, no sentido de atingir seu objetivo maior, a transformação da sociedade.

\section{Algumas considerações}

Na perspectiva de fornecer subsídios para uma leitura marxista no campo da educação popular, seguiu-se em uma direção crítica, que entende a educação como um amplo espaço para os mais diversos debates e opiniões variadas. Contudo, sem se eximir de optar por uma educação que busque contribuir com a transformação da sociedade que está posta, e que, sustentada pela filosofia da práxis educativa, segue em busca da conscientização e, por conseguinte, da práxis de seus educandos, mas sem desrespeitar o saber daqueles que compõem os setores populares.

Freire, apesar de não comungar com os determinismos históricos do(s) marxismo(s), recorre às idéias de Marx para ajudálo a entender melhor a problemática histórica global das camadas populares que ele já vinha trabalhando, tomando a práxis, categoria central da filosofia marxista, como uma das categorias fundamentais da educação popular. Tanto é que, para Freire, conforme Paludo (2001, p. 79), “[...] a superação da contradição opressor-oprimido, tanto da parte do opressor que se descobre opressor, quanto pelo oprimido que se descobre oprimido, não pode ser superada idealisticamente (no nível da consciência somente)", mas também da prática.

Enfim, no momento em que a educação popular busca a conscientização dos sujeitos sociais, explicando as formações ideológicas a partir da práxis material, demonstra que a transformação da realidade não é possível através da consciência, mas pela ação. Portanto, partindo da práxis presente no mundo concreto possibilita-se a consciência da práxis dos sujeitos sociais, dos quais depende a concretização da práxis coletiva.

Educ. e Filos., Uberlândia, v. 21, n. 42, p. 169-192, jul./dez. 2007. 


\section{Referências}

BOTTOMORE, T. Dicionário do pensamento marxista. Rio de Janeiro: Jorge Zahar editor, 2003.

CARDOSO, C. F. No limiar do século XXI. In: REIS FILHO, D. A.; FERREIRA, J.; e ZENHA, C. (Org.). O século XX:o tempo das dúvidas. 3.ed. Rio de Janeiro: Civilização Brasileira, 2005. p. 249-275.

CARVALHO, José Murilo de. Cidadania no Brasil: o longo caminho. 4.ed. Rio de Janeiro: Civilização Brasileira, 2003.

FREIRE, Paulo. Pedagogia do oprimido. Rio de Janeiro: Paz e Terra, 1977.

Desmistificação da conscientização. In: TORRES, C. A. Consciência e história: a práxis educativa de Paulo Freire. Coleção Paulo Freire $n^{\circ} 1$. São Paulo: Loyola, 1979. p.105-118.

GADOTTI, Moacir. Perspectivas atuais da educação. Porto Alegre: Artes médicas sul, 2000.

GADOTTI, M. e TORRES, G. Educação popular: utopia latinoamericana. São Paulo: Cortez/EDUSP, 1994.

HOBSBAWM. Eric. Era dos extremos: o breve século XX 1914 - 1991. Tradução de Marcos Santarrita. São Paulo: Companhia das Letras, 1995.

HOLLIDAY, Oscar J. Resignifiquemos las propuestas y prácticas de educación popular frente a los desafios históricos contemporâneos. Revista La Piragua, Cidade do Paraná, n. 21. Mayo 2004. Disponível em: 〈http:// www.ceaal.org/piragua/ Piragua_21version_preliminar.pdf . Acesso em: 10/01/2006.

HURTADO, Carlos N. Aportes para el debate latinoamericano sobre la vigência y proyección de la educación popular. Revista La Piragua, Cidade do Paraná, n. 21. Mayo 2004. Disponível em: ‘http:// 
www.ceaal.org/piragua/Piragua_21version_preliminar.pdf> Acesso em: 10/01/2006.

KONDER, L. O futuro da filosofia da práxis: o pensamento de Marx no século XXI. 2 ed. Rio de Janeiro: Paz e Terra, 1992.

MARX, K. Teses sobre Feuerbach. In: MARX, K.; ENGELS, F. A ideologia Alemã. Tradução de Frank Müller. Coleção a obra prima de cada autor $n^{0}$ 192. São Paulo: Martin Claret, 2005. p.117-120.

PALUDO, Conceição. Educação popular em busca de alternativas: uma leitura desde o campo democrático e popular. Porto Alegre: Tomo editorial, Camp, 2001.

SALES, Ivandro da C. Educação popular: uma perspectiva, um modo de atuar (alimentando um debate). In: SCOCUGLIA, A. C.; MELO NETO, J. F. Educação popular: outros caminhos. João Pessoa: Ed.UFPB, 1999. p.111-122.

SCOCUGLIA, Afonso Celso. A história das idéias de Paulo Freire e a atual crise de paradigmas. 3 ed. João Pessoa: Editora Universitária/ UFPB, 2001.

Exclusão social e educação popular no Brasil 500. In: SCOCUGLIA, A. C. e MELO NETO, J. F. Educação popular: outros caminhos. João Pessoa: Ed.UFPB, 1999. p.101-110.

SILVA, Francisco de Assis. História geral: antiga e medieval. v. 1. São Paulo: Ed. Moderna, 1985.

VÁZQUEZ, Adolfo Sanchez. Filosofia da práxis. 2 ed. Tradução de Luiz F. Cardoso. Rio de Janeiro: Paz e Terra, 1977. 